\title{
Penerimaan Diri Bagi Penyandang Disabilitas Netra
}

\author{
St. Rahmah \\ * Bimbingan dan Penyuluhan Islam, Fakultas Dakwah dan IImu Komunikasi, \\ Banjarmasin, Indonesia \\ *Email; strahmah12268@gmail.com
}

\begin{abstract}
Persons with disabilities are blind people who have a sense of sight (both) do not function as a channel of information in their activities as a normal person. This means that a blind person has a disability in the sense of vision so that the vision function is not the same as people in general. Disabilities in people with visual impairments have a major influence on daily life. The physical limitations of people with visual impairments hamper any activities that are normally carried out by normal (seeing) people. These limitations affect the mental condition of persons with blind disabilities, for example a feeling of inferiority towards the physical possessed, then fear and insecurity about their potential, this is a problem that must be faced by persons with blind disabilities. Persons with disabilities who are blind with imperfections of their sense of sight will naturally experience various problems including those related to their self-acceptance, because it is not easy for those with disabilities to be able to accept themselves, and will require a long time, until it is embedded in him that experiencing blindness is not the end of everything, and with limitations in their sense of sight they still have a strong desire and determination to realize their desires, and are able to adapt themselves to their circumstances and environment by seeing themselves as they really are and recognizing themselves as they really are. Persons with visual impairments, whether innate or not, who have self-acceptance they will have the confidence to face problems, have the same degree as others, can receive praise, be able to accept criticism, able to accept limitations and strengths that exist in themselves, have a positive assessment of himself, able to control his emotional state, and be responsible.
\end{abstract}


ABSTRAK

Penyandang disabilitas netra adalah seseorang yang memiliki indera penglihatannya (keduanya) tidak berfungsi sebagai saluran informasi dalam kegiatannya sebagaimana orang yang normal. Hal tersebut memiliki makna bahwa seorang disabilitas netra memiliki kelainan dalam indera penglihatan sehingga fungsi penglihatannya tidak sama dengan orang pada umumnya. Kelainan pada penyandang disabilitas netra memiliki pengaruh besar terhadap kehidupan sehari-hari. Keterbatasan fisik penyandang disabilitas netra menghambat setiap kegiatan yang umumnya dilakukan oleh orang normal (melihat). Keterbatasan yang dimiliki tersebut berpengaruh terhadap kondisi mental penyandang disabilitas netra, misalnya rasa minder terhadap fisik yang dimiliki kemudian rasa takut dan tidak percaya diri terhadap potensi yang dimiliki, hal tersebut merupakan problematika yang harus dihadapi oleh penyandang disabilitas netra. Penyandang disabilitas netra dengan ketidaksempurnaan indra penglihatan yang dimilikinya tentu akan mengalami berbagai permasalahan diantaranya berkaitan dengan penerimaan dirinya, karena bukanlah hal yang mudah bagi mereka penyandang disabilitas untuk dapat menerima dirinya, dan akan memerlukan waktu yang cukup lama, hingga tertanam dalam dirinya bahwa mengalami tunanetra bukanlah akhir dari segalanya, dan dengan keterbatasan pada indra penglihatan mereka tetap memiliki keinginan dan tekad yang kuat untuk mewujudkan keinginannya, serta mampu menyesuaikan dirinya terhadap keadaan dan lingkungannya dengan memandang diri seperti apa adanya dan mengenali diri sebagaimana adanya.Penyandang disabilitas netra baik bawaan maupun tidak yang memiliki penerimaan diri mereka akan mempunyai keyakinan untuk menghadapi persoalan, memiliki derajat yang sama dengan orang lain, dapat menerima pujian, mampu menerima kritikan, mampu menerima keterbatasan dan kelebihan yang ada pada dirinya, memiliki penilaian yang positif terhadap dirinya, mampu mengendalikan keadaan emosi, dan bertanggung jawab.

KATA KUNCI Penerimaan diri; penyandang disabilitas netra

\section{Pendahuluan}

Indra penglihatan merupakan salah satu indra yang sangat penting bagi individu dalam membantu mobilitas, dikarenakan indra penglihatan mempunyai fungsi untuk melihat, seperti untuk melihat suatu benda, mengenali orang dari wajah, membaca, berkendara, dan kegiatan-kegiatan lainnya, tetpi sebaliknya kalau indra penglihatan terganggu secara total atau tidak tentu akan berdampak terhadap aktivitas seseorang dalam kesehariannya.

Seseorang yang pada mulanya dapat menggunakan indra penglihatannya dengan baik kemudian menjadi tuna netra secara total ataupun tidak sudah pasti akan mengalami perubahan baik aspek fisik maupun kejiwaan sehingga pada akhirnya akan mempengaruhi terhadap peran dan status mereka di lingkungan sekitar. Karenanya mereka sangat membutuhkan penyesuaian serta harus mampu menerima diri dengan keadaan yang sekarang. Individu yang 
memiliki penerimaan diri yang baik akan lebih mudah untuk menerima keadaan diri apa adanya sehingga dapat menjalankan peran di masyarakat dengan baik, begitu pula sebaliknya.

Sesorang individu yang memiliki penerimaan diri rendah sangat rentan mengalami putus asa, karena selalu menyalahkan dirinya, malu, rendah diri dengan kondisi dirinya, merasa tidak berarti, merasa iri terhadap keadaan orang lain, dan pada akhirnya akan mengalami kesulitan dalam menciptakan hubungan yang baik dengan orang lain, dengan kata lain orang yang tidak mempunyai penerimaan yang baik bukan hal yang mudah untuk menerima keadaan dirinya sendiri. Banyak individu mengalami kesukaran dalam menerima kekurangan-kekurangan dirinya, dan sebagian besar dari mereka tidak dapat mencapai penerimaan secara optimal. Penerimaan diri merupakan salah satu aspek yang sangat penting pada seseorang penyandang disabilitas netra. Dengan penerimaan diri yang baik mereka penyandang disabilitas nerta akan mampu mengembangkan semua potensi yang dimilikinya dengan optimal dalam kehidupannya.

\section{Kajian Teori \\ Disabilitas Netra}

Manusia diciptakan Allah Swt dengan segala macam perbedaan dan keanekaragaman baik dari segi jasmani maupun rohani. Terdapat manusia yang sejak lahir memiliki kondisi tubuh normal, ada sebagian lagi yang sejak lahir memiliki kondisi tubuh tidak normal, tetapi, ada juga saat lahir dengan mempunyai kondisi tubuh yang normal namun dalam rentang waktu perjalanan hidupnya mereka mengalami musibah sehingga membuat tubuh mengalami cacat fisik yang menyebabkan seseorang kehilangan indra penglihatannya yang dikenal dengan sebutan tunanetra.

Menurut etimologi tunanetra berasal dari kata tuna berarti rusak dan kata netra berarti mata, dengan demikian perkataan tunanetra berarti rusak penglihatan, dan seseorang yang mengalami kerusakan penglihatannya disebut dengan tunanetra. Sedangkan orang yang buta adalah seseorang yang mengalami kerusakan penglihatannya seratus persen, karena itulah orang yang tunanetra belum tentu mereka mengalami gangguan penglihatannya seratus persen, namun seseorang yang buta tentu pasti tunanetra. (Pradopo, 1977)

Indra penglihatan yang tidak berfungsi lagi kendatipun dengan menggunakan berupa alat bantu dan senantiasa tergantung dengan bantuan fungsi indra lainnya dikenal dengan istilah buta, sedangkan indra penglihatan 
yang ketajamannya kurang, daya tahan rendah dan mempunyai kesulitan dengan aktivitasnya yang memerlukan penglihatan namun masih dapat membantu dengan bantuan alat khusus walaupun terbatas dikenal dengan istilah penglihatan yang kurang (low vision) (WHO), lebih jauh dikatakan bahwa seseorang yang dilahirkan tanpa penglihatan cahaya disebut dengan buta bawaan sedangkan buta didapat adalah setelah beberapa waktu sejak dilahirkan terjadi penurunan penglihatannya.

Heather Mason, dkk (1999) menyebutkan beberapa penyebab ketunanetraan dalam Purwaka (2007) antara lain:

1. Faktor genetik atau herediter, beberapa kelainan penglihatan didapat akibat diturunkan dari orang tua.

2. Perkawinan sedarah, banyak ditemukan ketunanetraan dari hasil perkawinan dekat.

3. Disebabkan proses kelahiran.

4. Penyakit yang akut sehingga berkomplikasi dengan organ mata, infeksi virus yang menyerang saraf dan anatomi mata, tumor otak yang menyerang pusat saraf organ penglihatan.

5. Terjadinya kecelakaan yang mengenai organ penglihatan

6. Diakibatkan oleh penggunaan obat tidak sesuai ketentuan seperti dosis yang melebihi takaran sehingga sangat membahayakan terhadap organ penglihatan.

7. Rusaknya organ-organ selaput mata yang tipis yang disebabkan oleh adanya infeksi binatang.

8. Daerah yang memiliki suhu udara panas sehingga mengakibatkan udara tidak stabil dan membawa bibit penyakit, pada daerah yang kering biasa ditemukan penyakit mata jenis trachoma.

Ketunanetraan dapat mengakibatkan diantaranya tiga keterbatasan yang serius terhadap kemampuan seseorang dan sangat berpengarug terhadap fungsi kognitif sebagaimana dikemukakan oleh Lownfiel. Tiga keterbatasan tersebut adalah: Pertama, keterbatasan dalam sebaran atau jenis pengalaman; Kedua, keterbatasan dalam kemampuan untuk bergerak didalam lingkungan, Ketiga, keterbatasan dalam interaksi sosial dalam lingkungan (Juang, 2005: 52). 
Ketidakmampuan atau cacat dalam Kamus Besar Bahasa Indonesia disebut disability, penyandang disabilitas adalah orang-orang yang memiliki perbedaan kemampuan yang seringkali dikenal dengan istilah difable atau sekarang ini lebih dikenal dengan istilah disabilitas.

Penyandang disabilitas bagian kelompok masyarakat yang beragam, diantaranya penyandang disabilitas yang mengalami disabilitas fisik, mental disabilities gabungan dari disabilitas físik dan mental. Disabilitas pun sangat beragam istilah penyandang. Sebagai penyandang cacat, Kementerian Pendidikan Nasional menyebut dengan istilah berkebutuhan khusus, sedangkan Kementerian Kesehatan menyebut dengan istilah Penderita cacat.

penyandang disabilitas netra adalah orang yang indra penglihatannya mengalami gangguan atau kerusakan sehingga indra penglihatannya tidak dapat berfungsi dengan baik. Mereka memiliki keterbatasan untuk melakukan berbagai aktivitas yang membutuhkan suatu penglihatan seperti melihat sekitar, menonton televisi, membaca, serta hal lainnya yang berkenaan dengan penglihatan, yang disebabkan dari banyak faktor. Menurut Sutjihati Somantri ada beberapa kondisi yang akan dialami oleh penyandang disabilitas netra sebagai berikut :

a. Penglihatannya berkurang ketajamannya sebagaimana penglihatan orang yang normal.

b. Pada lensa mata terdapat cairan tertentu sehingga menyebabkan terjadinya kekeruhan pada lensa.

c. Syarat otak mengalami kesulitan dalam mengendalikan posisi mata

d. Susunan syaraf pada otak yang berhubungan dengan indra penglihatan mengalami kerusakan. (Sutjihati Somantri, 2006: 66)

Menurut kemampuan melihat penyandang disabilitas netra dapat diklasifikasikan dua (2) kategori, sebagai berikut:

1. Buta, apabila tidak memiliki kemampuan untuk menerima rangsang cahaya dari luar (visusnya $=0$ ) sama sekali.

2. Low Vision, apabila masih memiliki kemampuan untuk menerima rangsang cahaya dari luar, dengan ketajamannya lebih dari 6/21, atau jika hanya memiliki kemampuan untuk membaca surat kabar pada headline nya saja (Somantri, 2005:67) 


\section{Hasil Penelitian dan Pembahasan}

\section{Urgensi Penerimaan Diri Bagi Penyandang Disabilitas Netra}

Penyandang disabilitas netra atau tunanetra dalam kehidupan pribadinya mempunyai masalah dalam fungsi penglihatannya pada kehidupan sehari-hari misalnya dalam mengurus diri sendiri, dalam proses pembelajaran pendidikan formal atau non formal juga masalah sosial emosional. Reaksi emosional yang menetap akan mempengaruhi perkembangan kepribadian dan berakibat terbentuknya kepribadian yang negatif dan tidak sehat. Penyandang disabilitas netra menjadi tidak percaya diri dan rendah diri menghadapi dunia lain, selain itu cenderung menimbulkan sikap kecurigaan, kebencian dan permusuhan (Ellah, 2005: 161)

Menurut Geniofam (2010) penyandang disabilitas netra mengalami hambatan dalam perkembangan kepribadian dengan timbulnya beberapa masalah antara lain:

1. Rasa curiga dengan orang lain, karena keterbatasan stimulus visual penyandang disabilitas netra terganggu kemampuannya untuk berorientasi dengan lingkungannya sehingga kemampuan beraktivitas pun akan terganggu dan mengakibatkan hilangnya rasa aman dan cepat curiga atau buruk sangka terhadap orang lain. .

2. Perasaan mudah tersinggung, Pengalaman sehari-hari yang sering menimbulkan perasaan kecewa dapat mempengaruhi dan menjadikan penyandang disabilitas netra emosional.

3. Ketergantungan berlebihan, sifat ketergantungan pada orang lain sangat dimungkinkan terjadi pada penyandang disabilitas netra, hal ini kemungkinan disebabkan oleh suatu sikap tidak mau mengatasi kesulitan diri sendiri dan cenderung selalu mengharapkan bantuan orang lain, karena itulah penyandang disabilitas netra harus diberikan kesempatan untuk menolong diri sendiri, berbuat dan bertanggung jawab.

Keadaan yang dialami penyandang disabilitas netra di atas seperti tidak memiliki tujuan yang jelas dalam kehidupan, gagal menjalin hubungan dengan orang lain, tidak mampu hidup mandiri, tidak memperoleh kesempatan dari lingkungan atau ditolak lingkungan, tugas perkembangan yang terhambat dan tidak dapat menerima keadaan diri sendiri membuat penyandang disabilitas netra tidak dapat berfungsi secara positif dalam kehidupan dan sangat rentan 
mengalami masalah psikologis, seperti perasaan cemas, tertekan, rendah diri, kesepian, strees dan depresi dalam kehidupannya.

Penerimaan diri dalam ilmu psikologi disebut self acceptance. Secara etimologi sefl acceptanceterdiri dari kata self yang berarti diri dan acceptance penerimaan. ( John M. Echols; 1976; 511) Penerimaan adalah proses, cara atau perbuatan menerima

Secara terminologi penerimaan diri adalah suatu sikap menerima terhadap semua pengalaman hidup yang ada pada diri, sejarah hidup, latar belakang hidup, lingkungan pergaulan, dan masa-masa yang pernah dilalui dalam rentang kehidupan. (Theo Riyanto; 2006; 4)

Penerimaan diri atau self acceptance adalah suatu kondisi dan sikap positif individu dalam bentuk penghargaan terhadap diri, mengetahui kemampuan dan kekurangan, tidak menyalahkan diri sendiri maupun orang lain dan berusaha sebaik mungkin agar dapat berubah menjadi lebih baik dari sebelumnya.

Penerimaan diri adalah bagaimana individu menerima dan memahami karakteristik kepribadiannya. Individu merasa mampu dan mau hidup sebagaimana kehidupan individu lain pada umumnya. Bila individu tersebut mampu memahami perilakunya maka ia akan menyukai dirinya dan merasa orang lain juga akan menyukai dirinya, akan tetapi bila individu tersebut tidak mampu memahami dirinya maka dia akan menolak atau memperbaiki hubungan dengan orang lain. (Schultz:1991:51)

Ada banyak hal yang dapat mempengaruhi penerimaan diri seseorang, salah satunya adalah pemahaman tentang dirinya, yaitu kemampuan untuk menemukan dirinya, dengan kata lain bahwa semakin seseorang mampu memahami dirinya sendiri tentu semakin baik seseorang mampu menerima dirinya.

Penerimaan diri sangat erat hubungannya dengan konsep diri yang positif, karena dengan konsep diri yang positif seseorang dapat menerima dan memahami fakta-fakta yang sangat berbeda dengan keadaan dirinya. Seseorang yang mampu menerima dirinya akan mempunyai evaluasi diri yang sebenarbenarnya dengan potensi pada dirinya, dan kemudian dapat dikombinasikan dengan penghargaan atas dirinya, meyakini kualitas diri sendiri tanpa harus 
dikendalikan oleh orang lain dan memiliki penilaian yang realistis mengenai keterbatasan tanpa harus mencela diri sendiri.

Lebih jauh dijelaskan bahwa penerimaan diri adalah suatu kemampuan untuk mempertahankan hal yang positif terhadap diri sendiri dan kehadiran suatu pengalaman. Penerimaan menunjukkan keseimbangan emosional yang disertai dengan melepaskan kesulitannyan untuk mendapatkan kembali apa yang telah hilang. Dengan demikian, seseorang yang menerima dirinya mudah untuk mempertahankan keseimbangan dan rasa kedamaian batin ( $\mathrm{Xu}$, Wei.,Marcus A, Zhang Q, Liu X: 2015 6:797-802)

Hurlock (1978) menjelaskan ada beberapa faktor yang mendukung individu dalam penerimaan diri:

1. Pemahaman tentang diri sendiri,. yaitu dengan adanya kepemahaman terhadap diri sendiri akan membuat seseorang dapat mengenali potensi kemampuan dan ketidakmampuannya, semakin seseorang bisa mengenali dirinya tentu semakin mudah untuk menerima dirinya.

2. Harapan yang realistik, yakni seseorang individu dapat menentukan sendiri suatu keinginan yang akan diraih sesuai dengan pemahaman dan potensi yang dimilikiinya, sehingga pada saat mencapai tujuannya akan membentuk kepuasan diri sendiri dan akhirnya membentuk sikap penerimaan terhadap diri sendiri.

3. Tidak adanya hambatan dalam lingkungan maksudnya yaitu seseorang yang sudah mempunyai keinginan yang realist tetapi karena lingkungan disekitarnya tidak memberikan kesempatan maka individu akan sulit untuk mencapainya.

4. Sikap masyarakat yang menyenangkan yaitu masyarakat mempunyai dugaan yang baik karena adanya pujian terhadap kemampuan sosial dan kesediaan individu untuk mengikuti kebiasaan di lingkungan masyarakat.

5. Tidak mengalami gangguan emosional yang sangat berat sehingga individu dapat bekerja atau beraktivitas sebaik mungkin, tekanan yang berat dan terus menerus seperti yang terjadi pada lingkungan kerja atau rumah, yang mana kondisi sedang tidak baik, bisa mengakibatkan gangguan yang berat, sehingga perilaku orang itu dinilai menyimpang dan orang lain menjadi terlihat selalu mencela dan menolak orang tersebut, karena gangguan emosi 
sekecil apapun bisa mengganggu keseimbangan individu.

Penerimaan diri dapat dibedakan menjadi dua yaitu penerimaan diri positif dan penerimaan diri negatif. Penerimaan diri positif adalah kemampuan seseorang dalam menghadapi perasaan, pikiran dan emosi tanpa penolakan atau penghindaran, dan penerimaan diri negatif melibatkan ketidakmampuan seseorang dalam menghadapi perasaan, pikiran, dan emosi, sehingga menyebabkan penolakan diri. (Neil Aldrin: 2012:.69)

Self acceptance atau penerimaan diri mempunyai peranan penting dalam kehidupan sosial, yang dapat meningkatkan kepercayaan diri serta memiliki hubungan baik dengan masyarakat, karena individu menyadari bahwa Allah menciptakan manusia dengan kodrat yang sama, semua memiliki kekurangan dan kelebihan.

Menerima diri apa adanya berarti jujur terhadap kondisi apapun yang dimiliki, tanpa ada yang disembunyikan baik kelebihan, kekurangan, kekuatan, kelemahan maupun hambatan yang ada dalam diri. Semua dijadikan secara seimbang tanpa meratapi kekurangan dan membanggakan kelebihan. Dengan penerimaan diri seseorang dapat mengoptimalkan potensi diri untuk mencapai keberhasilan. (Endra K. Prihadhi: 2004: 56-57) Semakin sering seseorang latihan penerimaan diri, tentu akan semakin gampang untuk mengakui kekuatan diri, mengapresiasi keberhasilan, menghadapi tantangan, terbuka terhadap umpan balik, dan lain sebagainya. (Robert Holden: 2007: 90)

Dengan demikian ada beberapa langkah yang harus dilakukan untuk menerima diri adalah pertama, belajar mengenali diri secara menyeluruh. Kedua, belajar untuk menghargai dan mengakui apa yang ada pada diri, tidak ada yang ditolak dan diingkari. Ketiga, menerima apapun yang dimiliki, sebagai anugerah yang istimewa dan unik terhadap semua yang ada. Keempat, bangga terhadap keberadaan diri, dan harus memuji diri sendiri.102(Theo Riyanto: 2006: 53)

Chaplin mengemukakan bahwa penerimaan diri adalah pada dasarnya sebuah sikap merasa puas dengan dirinya sendiri, kualitas-kualitas dan bakatbakat sendiri, serta pengakuan akan keterbatasan-keterbatasan diri sendiri.

Penerimaan diri ini mengandalkan adanya kemampuan diri pada psikologis seseorang, yang memberikan kualitas diri. Hal ini berarti bahwa tinjauan tadi akan diarahkan pada semua kemampuan diri yang mendukung 
terhadap kesadaran diri akan seluruh kelebihan dan kekurangan diri yang seharusnya seimbang dan diupayakan buat saling melengkapi satu sama lain, sebagai akibatnya dapat menumbuhkan kepribadian yang sehat.

Menurut Tentama (2010) bahwa diantara faktor yang mempengaruhi penerimaan diri individu adalah dengan berfikir positif. Kecenderungan individu yang berfikir positif akan membuat mereka bersemangat, lebih mampu memahami diri, yakin akan kemampuan yang dimilikinya dan mampu menjalani kehidupan yang optimis, hal ini akan menjadikan indivdu semakin menerima keadaan dalam dirinya. Pengaruh positif dari tingginya penerimaan diri pada individu akan menghasilkan seorang individu yang memiliki konsep diri positif, sehingga individu mampu memahami dan menerima perbedaan yang ada pada dirinya dan mampu menyesuaikan diri dengan seluruh pengalaman mentalnya serta mengevaluasinya (Calhoun \& Acocella, 1990). Sementara itu menurut Tentama (2012; 2012) individu yang memiliki penerimaan diri mampu beradaptasi dengan lingkungannya dan memiliki dorongan untuk mengembangkan dirinya sesuai dengan kemampuannya.

Setiap individu cenderung memiliki perbedaan dalam hal penerimaan terhadap dirinya dengan orang lain, ada beberapa ciri-ciri orang yang menerima dirinya menurut Johnson David sebagai berikut:

a. Menerima diri sendiri apa adanya

Disadari atau tidak, menerima diri sendiri itu hal yang tersulit buat dilakukan. acapkali seseorang merasa terlalu banyak kekurangan yang ada pada diri. Terlebih Bila didiagnosa memiliki suatu penyakit fisik atau psikis tertentu. Tentu hal tadi semakin sulit membentuk seseorang mendapatkan diri sendiri. tetapi, jika bisa menerima realita yang terdapat pada diri dengan ikhlas, tentunya pasti mendapatkan diri sendiri apa adanya.

Perasaan tulus, nyata dan jujur dalam memberikan penilaian terhadap diri sendiri merupakan tandanya seseorang dapat memahami dirinya, oleh karena itu kemampuan untuk memahami dirinya sangat tergantung dari kualitas intelektualnya dan kesempatan untuk menemukan dirinya, bahkan menyadari kenyataan diri dirinya. Sehingga pemahaman diri dan penerimanaan diri tersebut akan berjalan secara beriringan, semakin seseorang memahami tentang dirinya, maka semakin besar juga seseorang 
mampu untuk penerimaan dirinya.

b. Tidak menolak dirinya sendiri

Seseorang tidak akan menolak dirinya sendiri dengan memiliki jiwa selfacceptance, karena sepenuhnya dia menyadari dan memahami semua kekurangan dan kelemahan yang dimilikinya. Tidak menafikan kekurangan dan kelemahan yang ada dalam dirinya tersebut.

Sikap atau respon dari lingkungan akan membentuk sikap kepada diri seseorang. Karena seseorang yang mendapatkan perlakuan yang baik dan menyenangkan dari lingkungannya, cenderung akan menerima dirinya, dengan kata lain tidak menolak diri sendiri merupakan suatu sikap menerima kenyataan diri sendiri, tidak menyesali diri sendiri, tidak membenci diri sendiri, dan jujur pada diri sendiri.

c. Memiliki keyakinan untuk mencintai diri sendiri.

Pada waktu seseorang menghadapi kenyataan yang tidak diinginkan, tentu akan merasa memerlukam kehadiran atau cinta dari orang lain. Sementara seseorang tersebut tidak selalu mendapatkan cinta dari orang lain dan tidak selalu ada orang yang hadir saat seseorang merasa terpuruk. Padahal yang terpenting adalah cinta dari diri sendiri sehingga seseorang mampu menerima dirinya sendiri.

d. Untuk merasa bahagia, maka seseorang tidak perlu merasa benar-benar sempurna

ketidaksempurnaan yang dialami seseorang dalam hidup dapat membuat lebih bijak menghadapi hidup, cukup dengan memandang sisi positif yang ada dalam dirinya, sebab tidak ada manusia yang sempurna, sehingga memiliki kekuatan untuk menciptakan kebahagiaan sendiri, dengan cara terbaik yang bisa di lakukan sendiri.

e. Yakin memiliki kemampuan untuk menghasilkan kerja yang bermanfaat

Seseorang yang menerima dirinya dengan baik tentu akan menggunakan bakatnya sebaik mungkin. Dengan demikian, orang tersebut dapat bekerja atau menghasilkan karya yang berguna untuk masyarakat di sekitarnya.

Menerima keadaan diri sendiri bukanlah hal yang mudah, sekian banyak orang mengalami kesukaran dalam menerima kekurangan- kekurangan dirinya, 
dan sebagian besar dari mereka tidak dapat mencapai penerimaan secara optimal. Karena memandang diri serba baik akan membuat individu kesulitan untuk mengolah diri sendiri dan kesulitan untuk mengatasi problem kehidupan.

Penerimaan diri dalam Islam merupakan bagian dari kajian qana'ah. Arti qana'ah adalah merasa ridha dan cukup dengan pembagian rizki yang diberikan oleh Allah Swt. Qanaah merupakan suatu sikap yang rela menerima dan selalu merasa cukup dengan hasil yang sudah diusahakan serta menjauhkan diri dari rasa tidak puas juga perasaan kurang. Dan seseorang bisa disebut bersifat qonaah apabila memiliki pendirian dengan apa yang telah diperoleh atau bersyukur atas yang ada pada dirinya karena semua adalah kehendak Allah Swt. Dengan demikian qana'ah adalah sebuah implementasi kesempurnaan iman seseorang, karena dengan sifat qana'ah menggambarkan keridhaan terhadap segala ketentuan dan takdir Allah Swt, termasuk dalam hal pembagian rizki bagi orang yang memilikinya

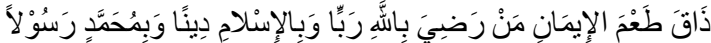

$$
\begin{aligned}
& \text { Rasulullah bersabda, "Akan merasakan kelezatan/kemanisan }
\end{aligned}
$$

(kesempurnaan) iman, orang yang ridha kepada Allah Swt. sebagai Rabb-nya dan Islam sebagai agamanya serta (nabi) Muhammad Saw. Sebagai Rasulnya" (HR. Muslim)

Ridha kepada Allah sebagai Rabb, merupakan ridha terhadap semua perintah dan larangan Allah Swt, terhadap segala ketentuan-Nya, dan terhadap semua apa yang diberikan dan yang tidak diberikanNya.

Keridhaan manusia adalah ketenangan jiwa dalam menerima nasib baik atau pun nasib buruk dan ketegaran spiritual didalam menerima berbagai persoalan kehidupan. Bagi orang-orang yang mempunyai rasa ridha terhadap penderitaan yang diberikan oleh Allah Swt kepadanya, mereka akan senantiasa merasa ikhlas. Mereka ridha atas pemberian-pemberian Allah, mereka ridha bahagia di dunia ini, mereka ridha terhadap bermacam-macam ujian dan pilihan Allah walaupun tidak sesuai dengan kehendak diri mereka. Termasuk pula keridhaan atau penerimaan diri penyandang disabilitas netra atas keadaan atau takdir terhadap dirinya.

Pada dasarnya anggota tubuh yang memiliki kesempurnaan atau kenormalan adalah anggota tubuh yang memiliki nilai keberkahan disisi Allah 
Swt. Anggota tubuh yang berkah adalah setiap anggota tubuh yang diberikan Allah sebagai amanah apabila digunakan sesuai dengan tugas dan fungsinya agar mendapatkan nilai ibadah disisi Allah. Sesuai dengan Firman Allah surat alDzariyat ayat 56 :

$$
\text { وَمَا خَلَقْتُ الْجِنَّ وَالْإِنْسَ إِلَّ لِيَعْبُدُوُنِ }
$$

Artinya : Dan Aku tidak menciptakan jin dan manusia melainkan supaya mereka mengabdi kepada-Ku.

Jaminan kebahagiaan dalam hidup manusia dapat dilihat dari cara mempergunakan seluruh organ tubuh semata-mata untuk beribadah dan beramal shaleh dengan tujuan mendapat ridha Allah.( Habib Syarief Muhammad Alaydrus :2009; 210) Jadi sudah jelas bahwasanya kebahagiaan dan keberkahan hidup bukan ditentukan dari segi kesempurnaan atau kenormalan organ tubuh, namun kenyataannya banyak dari manusia yang menilai kebahagian hidup dilihat dari fisik luar semata, khususnya penyandang disabilitas netra banyak yang tidak mampu menerima keadaan dan kekurangan salah satu organ tubuhnya.

Kemampuan untuk dapat menerima segala kekurangan dan keterbatasan merupakan solusi dalam mencapai sebuah ketenangan, dengan demikia penyandang disabilitas netra akan memandang dirinya lebih memiliki sesuatu yang positif, mempunyai keyakinan akan kemampuan dirinya untuk meraih kesuksesan, berfikir akan kelebihan yang pasti dimiliki oleh setiap orang dan tidak memperdulikan kekurangan yang ada sebagai penghalang dalam menjalani kehidupan.

Disamping ridha dengan bersyukur akan membuat seseorang memiliki pandangan yang lebih positif dan perpektif secara lebih luas mengenai kehidupan, yaitu pandangan bahwa hidup adalah sebuah anugerah yang diberikan Allah Swt kepadanya dan bersyukur sebagai rasa berterimakasih dan bahagia sebagai respon penerimaan karunia tersebut.

Dengan bersyukur dan ridha seseorang akan menerima apa yang ada dalam dirinya. Setiap orang memiliki keterbatasan ataupun kekurangan dalam hidup, namun dengan cara menerima keadaan diri apa adanya, dengan rasa terima kasih, pemikiran yang positif, menerima atau mendapatkan sesuatu yang pada akhirnya dapat memberikan suatu kebahagiaan, perasaan nyaman dapat meningkatkan rasa syukur. Hal ini sesuai dengan firman Allah SWT dalam surat 
Luqman ayat 22:

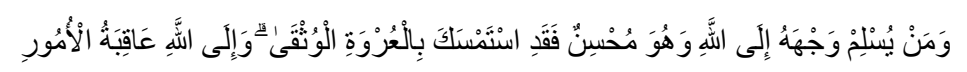

"Dan barang siapa yang menyerahkan dirinya kepada Allah, sedang dia orang yang berbuat kebaikan, maka sesuangguhnya ia telah berpegang kepada buhul tali yang kokoh. Dan hanya kepada Allah-lah kesudahan segala urusan."

Ridha merupakan tetapnya hati dalam ketenangan dan ketenteraman ketika mengalami sesuatu yang akan membuat seseorang kesakitan. Karena ketenangan hati dan ketenteraman jiwa terhadap ketetapan dan takdir Allah s.w.t., disertai kemampuan menyikapinya dengan tabah, termasuk terhadap derita, nestapa, dan kesulitan yang muncul darinya yang dirasakan oleh jiwa.

Seseorang yang ridha akan menerima apa saja apapun yang telah dan sedang dialami, karena itu adalah yang terbaik bagi dirinya dan tidak ada yang lebih baik selain apapun yang telah dan sedang dialaminya adalah kehendak Allah Swt sebagai bukti atau penerimaan dirinya, sehingga lebih kuat terhubung pada emosi positif daripada emosi negatif dan menunjukkan keterkaitan yang positif dengan penerimaan diri.

Menurut Hurlock (2009) bahwa seseorang yang menyukai atas dirinya tentu lebih dapat untuk menerima dirinya sehingga ia semakin baik diterima oleh orang lain, dengan kata lain bahwa seseorang yang memiliki penerimaan diri yang baik akan lebih mampu mengendalikan emosinya pada hal yang positif diantaranya dengan mengucap syukur. bersyukur dan penerimaan diri merupakan satu hal yang berkaitan. Seseorang yang memiliki penerimaan diri yang baik, maka ia mampu melihat diri sendiri dari sisi positif, menerima serta mengakui segala kelebihan maupun segala keterbatasan yang ada dalam dirinya, sehingga akan membuat seseorang akan bersyukur dengan apa yang ia miliki sekarang dan mengarahkan ke emosi yang positif, serta membuat seseorang akan dapat melakukan evaluasi yang positif dalam hidupnya.

\section{Simpulan}

Penyandang disabilitas netra adalah seseorang yang indra penglihatannya mengalami gangguan atau kerusakan sehingga indra penglihatannya tidak dapat berfungsi secara normal. Penyandang disabitas netra yang mampu menerima dirinya dengan segala kekurangan dan keterbatasannya 
.akan memandang dirinya lebih memiliki sesuatu yang positif, mempunyai keyakinan akan kemampuan dirinya untuk meraih kesuksesan, berfikir akan kelebihan yang pasti dimiliki oleh setiap orang dan tidak memperdulikan kekurangan yang ada sebagai penghalang dalam menjalani kehidupan dalam mengembangkan diri sehingga dapat menjalani hidup dengan baik dan penuh tanggung jawab.

Penerimaan diri sangat penting pada seseorang penyandang disabilitas netra. Dengan adanya penerimaan diri seorang penyandang disabilitas netra akan mampu mengaktualisasikan segala potensi yang dimilikinya, dan akan membantu individu untuk dapat berfungsi secara ideal sehingga dapat mengembangkan segala kemampuan dan potensi yang dimiliki dengan optimal dalam kehidupannya.

\section{Referensi}

Arthur S. Reber, Emily S. Reber, The Penguin Dictionary of Psychology, Terj. Yudi Santoso, Kamus Psikologi Indonesia, Pustaka Pelajar, Yogyakarta, 2010.

Calhoun, J. F, \&Acocella, J. R., Psychology of adjustment and human relationship. Mc McGraw-Hill Publishing Company, New York, 1990.

Chalidah, Ellah Siti. Departemen Pendidikan Nasional. Terapi Permainan Bagi Anak Yang Memerlukan Layanan Pendidikan Khusus. Jakarta: Direktorat Pembinaan Pendidikan Tenaga Kependidikan Dan Ketenagaan Keperguruan Tinggi, 2005.

Chaplin, J.P. Kamus Lengkap Psikologi. Jakarta: Raja Grafindo Persada, 2005.

Dewi, D. S. Kajian tentang psychological well being pada anak tunanetra di sekolah menengah atas luar biasa. Psychology \& Humanity, 2016.

Endra K. Prihadhi, My Potency, PT Elex Media Komputindo, Jakarta, 2004.

Geinofam, Mengasuh \& Mensukseskan Anak Berkebutuhan Khusus, Gerailmu, Yogyakarta, 2010.

Habib Syarief Muhammad Alaydrus, Agar Hidup Selalu Berkah Meraih Ketentraman Hati dengan Hidup Penuh Berkah, Mizan, Bandung, 2009,

Hurlock, EPersonality development, McGraw-Hill Publishing Company, Tokyo, 1978.

John M. Echols, An English-Indonesian Dictionary, Terj. Hassan Shadily, Kamus Inggris Indonesia, Gramedia Pustaka Utama, Jakarta, 1976.

Meity Taqdir Qodratillah, Kamus Bahasa Indonesia, Badan Pengembangan dan Pembinaan Bahasa, Kementrian Pendidikan dan Kebudayaan, Jakarta, 2011.

Muk Kuang, Amazing Life, PT Gramedia Pustaka Utama, Jakarta, 2010.

Neil Aldrin, Design Your Life, Puspa Swara, 2012.

Pradopo, S. Pendidikan Untuk Anak-anak Tunanetra Untuk Guru SGPLB, Departeman Pendidikan Dan Kebudayaan, Jakarta, 1977 
Robert Holden, Sucess Intelligence: Timeless Wisdom for a Manic Society, Terje. Yuliani Liputo, Success Intelligence, Mizan, Bandung, 2007.

Schultz, Psikologi Pertumbuhan: model-model kepribadian sehat (Yogyakarta: Kanisius, 1991.

Sutjihati Soemantri., Psikologi Anak Luar Biasa, PT Refika Aditama, Bandung, 2012.

Tentama, F. Berpikir positif dan penerimaan diri pada remaja penyandang cacat tubuh akibat kecelakaan, Humanitas, 2010.

Theo Riyanto, Jadikan Dirimu Bahagia, Kanisius, Yogyakarta, 2006.

Eko Riyadi dkk., Vulnerable Groups, Kajian dan Mekanisme Perlindungannya, PUSHAM UII,Yogyakarta. 2012.

Xu, Wei., Marcus A, Zhang Q, Liu X. The Mediating Effect of Self-Acceptance in the Relationship Between Mindfulness and Peace of Mind. JournalMindfulness (dipublikasikan).Department of Psychology and Neuroscience. USA: Duke University, 2015. 